\title{
The Educational Roles of Primary and Secondary School Teacher- Librarians in Hong Kong
}

\author{
Peter Warning \\ University of Hong Kong \\ Faculty of Education \\ Pokfulam Road \\ Hong Kong \\ pwarning@hku.hk \\ Chan Chun Ho Randolph \\ University of Hong Kong \\ Faculty of Education \\ Pokfulam Road \\ Hong Kong \\ randolphchan@gmail.com \\ Ma Hing Yuk Bernie \\ University of Hong Kong \\ Faculty of Education \\ Pokfulam Road \\ Hong Kong \\ bernie.yuk@gmail.com \\ Chu Samuel Kai Wah \\ University of Hong Kong \\ Faculty of Education \\ Pokfulam Road \\ Hong Kong \\ samchu@hku.hk \\ Wu Wendy Wai Yue \\ University of Hong Kong \\ Faculty of Education \\ Pokfulam Road \\ Hong Kong \\ wendywu@hku.hk
}

\begin{abstract}
This study explores the professional development and current work situation of Teacher-librarians (TLs) in primary and secondary schools in Hong Kong, and investigates and compares the educational roles of primary and secondary schools $T L s$ in teaching subject courses, developing stakeholders' information literacy, collaborating with teachers and cultivating students' reading habits. Key findings include: relatively more secondary school TLs have professional qualifications; secondary school TLs spend on average more than one-quarter of their time teaching subject (non-library related) courses, compared to primary school TLs (15\%), which they see as restricting their ability to provide library services; primary school TLs spend more time on the preparation and delivery of library lessons than secondary school TLs; both primary and secondary TLs spend less that $5 \%$ of their time collaborating with teachers; and that primary school TLs appear to have a more holistic approach to information literacy acquisition.
\end{abstract}


Keywords: Teacher librarians, Hong Kong, educational roles, collaboration, survey

\section{Introduction}

Teacher-Librarians (TLs) are educational leaders who infuse information literacy in curricula delivery and collaborate actively with other teachers in facilitating the development of information literacy in schools (Rosenfeld \& Loertscher, 2007). The launch of the New Senior Secondary (NSS) curriculum, with a stronger emphasis on inquiry based learning, there is a growing demand for information literacy training among students in Hong Kong. The educational role of TLs has become more significant as partners for teachers implementing inquiry-based project work, as they conduct information literacy programs and scaffold students' development by participating in students' inquiry-based project work.

While the importance of including TLs in collaborative teaching has been increasingly acknowledged (Chu, 2009; Kafai and Bates, 1997; Kuhlthau et al., 2007), the educational roles of TLs are mostly under-valued in various regions and countries (Doskatsch, 2003; McCarthy, 2002; Mokhtar and Majid, 2006). In addition to low collaboration levels between subject teachers and TLs, Mokhtar and Majid (2006) observed that school librarians were usually neglected and denied by subject teachers as educational counterparts. In light of this phenomenon, this study aims to present a more comprehensive understanding of the professional development and current work situation of TLs in Hong Kong. Additionally, it identifies and compares the educational roles of TLs in primary and secondary schools.

\section{Literature Review}

\section{Professional development of Teacher-Librarians}

Rapid advances in educational technology and the changing literacy landscape in the Twentyfirst Century have led to TLs transforming into a library media professional and information specialist (McCracken, 2001). TLs play an essential role in developing book collections in school libraries and designing appropriate reading programs that enhance students' reading abilities. Moreover, TLs are generally experts in information literacy. They are able to "encompass knowledge of one's information concerns and needs, and ability to identify, locate, evaluate, organize and effectively create, use and communicate information to address issues or problems at hand" (U.S. National Commission on Library and Information Science, 2003).

Prior research demonstrates that integrated library programs can have a positive impact on students' achievements and collaboration when "the teacher-librarian has experience as a classroom teacher, qualifications in teacher-librarianship and information studies and learning resources management, preferable at the graduate level" (Haycock and Jopson, 1999, p. 18). Regarding the educational qualifications of TLs, Abdullah (1998) also suggests that a master's degree should be considered as the entry-level degree for the TL profession.

The Association for Teacher-librarianship in Canada (1998) developed a list of professional competencies for TLs. They are:

a. placing a priority on staff relationships and leadership in the implementation of change.

b. providing leadership in collaborative program planning and teaching to ensure both physical and intellectual access to information and commitment to voluntary reading.

c. knowing curriculum programs mandated by the province, district and school.

d. understanding students and their social, emotional and intellectual needs.

e. having expert knowledge in evaluating learning resources in different formats and media, both on-site and remote, to support the instructional program. 
f. developing and promoting the effective use of informational and imaginative resources in all formats through cooperative professional activities

g. providing appropriate information, resources or instruction to satisfy the needs of individuals and groups.

h. using appropriate information technology to acquire, organize and disseminate information.

i. managing library programs, services and staff to support the stated goals of the school.

j. evaluating program and services.

(Association for Teacher-librarianship in Canada et al., 1998, p. 23-24).

\section{Educational roles of Teacher-librarians}

Information literacy is defined as "the ability to use information meaningfully in all aspects of our lives" (Kuhlthau, 2003, p.3). Contemporary students need to possess information and search skills because the competence to "access, evaluate and use information from a variety of sources is central to successful learning" (Scheirer, 2000). As TLs are information specialists, it is important for them to take a proactive role in teaching and guiding students how to develop, locate, retrieve, evaluate and use information critically and ethically. In addition to instilling information skills in students, TLs also equip other stakeholders with the knowledge of information literacy. TLs are trained to locate resources, to evaluate information, and to select materials, so they can apply information skills across curricula and grades, and educate other teachers about information literacy (Baule, 1999; Hylen, 2005).

TLs work with subject teachers in curriculum development and delivery through collaborative planning and teaching (Scheirer, 2000). Prior research indicates that "test scores rise in both elementary and middle schools as library media specialists and teachers work together" (Lance, Rodney, \& Hamilton-Pennell, 2000, p. 7). Lance, Welborn and Hamilton-Pennell (1992) also note that students demonstrate superior academic achievement when TLs assist in preparing teaching materials, or when they cooperate with subject teachers in planning instructional units. It illustrates that partnerships between teachers and TLs can result in better teaching and learning outcomes because the subject teachers know the course content intimately whereas TLs are more capable at addressing the students' information needs and infusing information skills in the curriculum (Hylen, 2005).

Recent studies also indicate that the collaborative teaching between language teachers, subject teachers and TLs can facilitate students' acquisition of information literacy and information technology skills, and promote the students' reading abilities and interest (Chu, Chow, \& Tse, 2011; Chu, Tse, Loh, \& Chow, 2011). Although researchers acknowledge the importance of the inclusion of TLs in collaborative teaching (Chu, 2011; Kafai and Bates, 1997; Kuhlthau et al, 2007), the role of TLs is under-valued in practice (Doskatsch, 2003; McCarthy, 2002; Mokhtar and Majid, 2006). Mokhtar and Majid (2006) examined the collaboration between teachers and school librarians in Singapore primary and secondary schools and found that the level of such collaboration was very low. Worse still, teachers did not even view school librarians as educational counterparts.

The importance of TLs as advocates for improving reading ability and fostering reading interest is widely recognized by educators and researchers (Fisher, 2008; Yip, 2007). Ogunrombi and Adio (1995) identified that the lack of functional libraries in schools, the unavailability of trained librarians and the failure to provide library periods are some inhibiting factors for developing reading habits among secondary school students. Since TLs are responsible for managing the precious resources in the library, it is important for them to employ a strategic use of library materials in order to establish a strong reading culture (Scheirer, 2000). 
As Broaddus and Ivey (2002) suggest, maintaining a wide range of library collections on topics under investigation and allotting time for students to read in class can support readers regardless of their motivation and ability. Fisher (2008) also notes that TLs can nurture students' reading habits by regularly introducing specific texts for specific students, actively engaging them with nontraditional texts, and creatively using Web 2.0 technologies to let students share and produce their reading products.

\section{Research Objectives}

Based on the research problem discussed earlier, i.e. gaining a more comprehensive understanding of the professional development and current work situation of TLs in Hong Kong, this study attempts to address the following research objectives:

- to explore the professional development of TLs in Hong Kong

- to identify the current situation of primary and secondary school TLs in Hong Kong

- to investigate and compare the educational roles of primary and secondary schools' TLs in teaching subject courses, developing stakeholders' information literacy, collaborating with teachers and cultivating students' reading habits.

\section{Methods}

This study used a mixed methods research design, combining quantitative and qualitative data to generate a more in-depth understanding of the educational roles of TLs in primary and secondary schools in Hong Kong.

\section{Participants}

This study involved 56 TLs from primary $(n=28)$ and secondary schools $(n=28)$ in Hong Kong. They were selected on a simple random sampling basis from the school database. The sampled participants were interviewed by telephone, email, and face-to-face communication.

\section{Data collection}

Two data collection methods were employed in this research. First, self-report questionnaires were distributed to the participants via email, fax, and in-person. Subjects were required to provide their demographic information and respond to a standardized set of questions about the educational role of TLs in: subject teaching, developing stakeholders' information literacy, collaborating with teachers, and cultivating students' reading habits. The survey utilized a fivepoint Likert-type scale (-2 being "strongly disagree", -1 being "disagree", 0 being "neutral", 1 being "agree", and 2 being "strongly agree"). Open-ended probes were also included to surface additional comments on their current situations and educational capacities as TLs.

Additionally, semi-structured interviews were conducted with 5 selected participants to understand their perceptions about the educational roles of TLs. The first part of these interviews contained questions developed from the results obtained from the survey. In the second part of the interviews, TLs were required to answer some open-ended questions to further describe their perceived roles in developing information literacy and reading habits among students.

\section{Data analysis}

The statistical data obtained in the survey were analyzed using SPSS version 19.0. Responses from the Likert-type scales were summarized using descriptive statistics. Mann-Whitney tests were also employed to compare the perceived educational roles between primary and secondary TLs. Statistical significance level was set at $p<0.05$, associated with a $95 \%$ confidence interval. 
The semi-structured interviews with the respondents were analyzed qualitatively. The researchers first reviewed and analyzed the interview transcripts to identify excerpts pertaining to descriptions and explanations for the current work situations and educational roles of TLs in Hong Kong. These excerpts were then organized and categorized according to the type of educational roles involved.

\section{Results and Discussion}

\section{Professional background and development of TLs in Hong Kong}

Primary and secondary school TLs gained knowledge and skills in librarianship through a similar process of professional development. Table 1 demonstrates that the respondents pursue professional development by attending training courses, self-learning, broadening professional networks or communication channels, participating in conferences related to the library profession and visiting other school libraries.

Table 1: Professional Development of TLs

\begin{tabular}{|l|c|c|c|}
\hline \multicolumn{1}{|c|}{$\begin{array}{c}\text { I strengthen my professional } \\
\text { development through: }\end{array}$} & $\begin{array}{c}\text { Primary school } \\
\text { TLs } \\
(\mathrm{n}=28)\end{array}$ & $\begin{array}{c}\text { Secondary school } \\
\text { TLs } \\
(\mathrm{n}=28)\end{array}$ & $\begin{array}{c}\text { Sig. } \\
\text { Mann-Whitney }\end{array}$ \\
\cline { 2 - 4 } & Mean (SD) & $1.29(0.53)$ & 0.605 \\
\hline $\begin{array}{l}\text { Attending training courses (e.g. } \\
\text { Information Literacy, cross- } \\
\text { curriculum reading, and topics about } \\
\text { supporting General Studies courses) }\end{array}$ & $1.36(0.56)$ & $1.21(0.42)$ & 0.683 \\
\hline $\begin{array}{l}\text { Self-learning (e.g. reading } \\
\text { publications related to my work) }\end{array}$ & $1.25(0.59)$ & $0.96(0.64)$ & 0.171 \\
\hline $\begin{array}{l}\text { Broadening my professional network } \\
\text { /communication channels (e.g., } \\
\text { being a professional member of } \\
\text { Hong Kong Library Association) }\end{array}$ & $1.18(0.77)$ & $1.00(0.61)$ & 0.114 \\
\hline $\begin{array}{l}\text { Participating in conferences related } \\
\text { to my profession }\end{array}$ & $1.25(0.52)$ & $1.18(0.48)$ & 0.928 \\
\hline Visiting other school libraries & $1.14(0.71)$ & & \\
\hline
\end{tabular}

Notes: * indicates $p<.05$

$-2=$ Strongly Disagree, $-1=$ Disagree, $0=$ Neutral, $1=$ Agree, $2=$ Strongly Agree

As shown in Table 2, $14 \%$ of primary school TLs did not receive any formal librarianship training whereas all secondary school TLs had or are undertaking formal librarianship training. In terms of work experience, the majority of the primary school respondents $(M=43 \%)$ had $10-14$ years of work experience as TLs, whereas $62 \%$ of the secondary school respondents have worked for less than four years in school libraries (Table 3). This indicates that the secondary school respondents in this study tend to possess higher-level educational qualifications in librarianship while the primary school respondents have more hands-on work experience of being TLs.

Table 2: Professional Qualification of TLs in Primary and Secondary Schools

\begin{tabular}{|l|c|c|}
\hline \multicolumn{1}{|c|}{ Formal Librarianship Training } & $\begin{array}{c}\text { Primary school } \\
\text { TLs } \\
(n=28)\end{array}$ & $\begin{array}{c}\text { Secondary school } \\
\text { TLs } \\
(n=28)\end{array}$ \\
\hline Do not receive any formal librarianship training & $14 \%$ & $0 \%$ \\
\hline
\end{tabular}




\begin{tabular}{|l|l|r|r|}
\hline Diploma in Teacher Librarianship & Studying & $4 \%$ & $52 \%$ \\
& Completed & $46 \%$ & $32 \%$ \\
\hline Bachelor in Library \& Information & Studying & $4 \%$ & $0 \%$ \\
Management & Completed & $25 \%$ & $5 \%$ \\
\hline Master in Library \& Information & Studying & $0 \%$ & $5 \%$ \\
Management & Completed & $21 \%$ & $23 \%$ \\
\hline
\end{tabular}

Table 3: Years of Experience of TLs in Primary and Secondary Schools

\begin{tabular}{|l|c|c|}
\hline $0-4$ year(s) & $25 \%$ & $62 \%$ \\
\hline $5-9$ years & $11 \%$ & $23 \%$ \\
\hline $10-14$ years & $43 \%$ & $4 \%$ \\
\hline Over 14 years & $14 \%$ & $12 \%$ \\
\hline
\end{tabular}

Primary and secondary school TLs have a similar perceived level of information literacy. Table 4 shows that both primary and secondary school TLs agree that they have the ability to teach students in: identifying information needs, identifying relevant information sources, formulating search strategies, evaluating the information found and using information ethnically. For example, a primary school TL commented that, "I can relate the library resources to the curriculum according to students' need" while another TL also noted that, "I can understand what my students needed and select the suitable information sources for them".

Table 4: Information Literacy of TLs

\begin{tabular}{|l|c|c|c|}
\hline \multicolumn{1}{|c|}{$\begin{array}{c}\text { I am confident in teaching the } \\
\text { following areas of Information } \\
\text { Literacy: }\end{array}$} & $\begin{array}{c}\text { Primary school } \\
\text { TLs } \\
(\mathrm{n}=28)\end{array}$ & $\begin{array}{c}\text { Secondary school } \\
\text { TLs } \\
(\mathrm{n}=28)\end{array}$ & Mann-Whitney \\
\cline { 2 - 4 } & Mean (SD) & $0.75(0.84)$ & 0.279 \\
\hline $\begin{array}{l}\text { a. Identify information needs for a } \\
\text { problem on hand. }\end{array}$ & $0.93(0.86)$ & $0.71(0.90)$ & 0.255 \\
\hline $\begin{array}{l}\text { b. Identify relevant information } \\
\text { sources / databases. }\end{array}$ & $0.97(0.64)$ & $0.86(0.76)$ & 0.371 \\
\hline $\begin{array}{l}\text { c. Formulate different kinds of } \\
\text { search strategies for inquiry-based } \\
\text { learning projects. }\end{array}$ & $1.04(0.74)$ & $0.86(0.80)$ & 0.158 \\
\hline d. Evaluate the information found. & $1.14(0.52)$ & $0.96(0.83)$ & 0.382 \\
\hline $\begin{array}{l}\text { e. How to use information ethically, } \\
\text { e.g. referencing. }\end{array}$ & $1.18(0.67)$ & & \\
\hline
\end{tabular}

Notes: * indicates $\mathrm{p}<.05$

$-2=$ Strongly Disagree, $-1=$ Disagree, $0=$ Neutral, $1=$ Agree, $2=$ Strongly Agree

\section{Current situation of TLs in Hong Kong}

The workload distribution of primary school TLs differs from that of secondary school TLs. As indicated in Figure 1, secondary school TLs spend a larger proportion of time on administration of the school library $(M=30.00 \%)$ and preparing and teaching subject courses $(M=27.04 \%)$ as compared to primary school TLs. For instance, a TL mentioned that she was responsible for, "handling library administration, such as updating news on new books, updating relevant archives regularly and arranging books in order". In contrast, primary school TLs were more involved in preparing and teaching library lessons $(M=21.03 \%)$ than primary school TLs. For example, a primary school TL said that she teaches students, "how to use different types of searching in online search engines and evaluate the source for their projects" during library lessons. However, both primary and secondary school TLs spend less than $10 \%$ of their time 
collaborating with teachers in curriculum development and teaching information skills collaboratively with teachers.

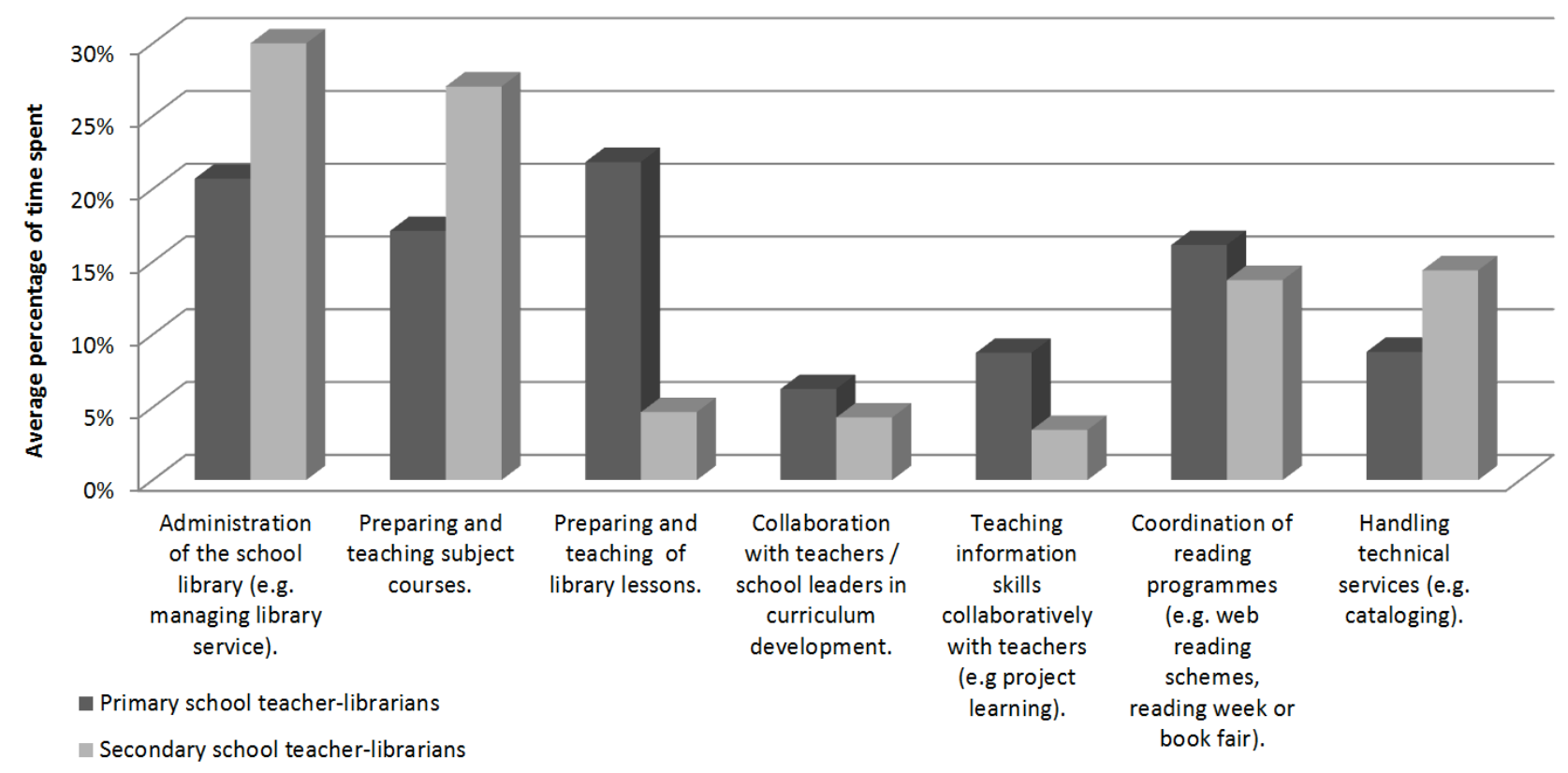

Figure 1: Workload distribution of primary and secondary school TLs in Hong Kong

\section{Educational roles of TLs in Hong Kong}

As shown in Table 5, there is a statistically significant difference over the perceived role of TLs in course instruction between primary and secondary school TLs $(p=0.017)$. Primary school TLs generally disagreed that subject teaching is part of the professional role of a $T L(M=-0.61)$ while secondary school TLs tended to be neutral to the statement $(M=0.07)$. This finding further shows that $62 \%$ of primary school TLs believed that a TL should not be involved in teaching a subject course whereas only $32 \%$ of secondary school TLs agreed with the statement.

The Mann-Whitney test demonstrates that there is a significant difference over the perceived benefits of subject teaching between primary and secondary school TLs $(p=0.003)$. Secondary school TLs agreed that a moderate amount of subject teaching helps them to successfully carry out their professional roles $(M=0.73)$, whereas primary school TLs were neutral towards the statement $(\mathrm{M}=0.07)$. A secondary school TL noted that, "engaging in teaching can allow the librarians to understand more about the contemporary education syllabus ... and integrate library lesson knowledge into core subjects". These findings indicate that secondary school TLs are more inclined to consider subject-course teaching as one of the educational roles of TLs, compared to their primary school counterparts.

Despite different views about subject teaching as a role of a $T L$, both primary $(M=0.52)$ and secondary school TLs $(M=0.64)$ agreed that the amount of subject teaching has restricted them from effectively carrying out the professional roles of a TL. One primary school TL mentioned that, " $m y$ role is to assist the subject teacher in preparing project teaching materials if they need to use some library tools for P1 to P6. If I were to teach a core subject, there wouldn't be enough time".

Table 5: The Roles of TLs in Subject Teaching

\begin{tabular}{l|l|l|l} 
TLs and subject teaching & Primary school & Secondary school & Sig.
\end{tabular}




\begin{tabular}{|l|c|c|c|}
\hline & $\begin{array}{c}\text { TLs } \\
(n=28)\end{array}$ & $\begin{array}{c}\text { TLs } \\
(n=28)\end{array}$ & Mann-Whitney \\
\cline { 2 - 4 } & Mean (SD) & Mean (SD) & $p$ value \\
\hline $\begin{array}{l}\text { Subject teaching is part of the } \\
\text { professional role of a TL. }\end{array}$ & $-0.61(1.03)$ & $0.07(1.09)$ & $0.017^{*}$ \\
\hline $\begin{array}{l}\text { The level of subject teaching has } \\
\text { restricted me from effectively } \\
\text { carrying out the professional roles } \\
\text { of a TL. }\end{array}$ & $0.52(0.98)$ & $0.64(0.87)$ & 0.427 \\
\hline $\begin{array}{l}\text { A moderate amount of subject } \\
\text { teaching helps me to successfully } \\
\text { carry out my professional roles. }\end{array}$ & $0.07(0.87)$ & $0.73(0.83)$ & $0.003^{*}$ \\
\hline
\end{tabular}

Notes: * indicates $\mathrm{p}<.05$

$-2=$ Strongly Disagree, $-1=$ Disagree, $0=$ Neutral, 1=Agree, 2=Strongly Agree

\section{Developing stakeholders' information literacy}

Primary and secondary school TLs shared similar perspectives on the role of TLs in developing information literacy among stakeholders. As shown in Table 6, both groups agreed that they infuse subject courses with elements of information literacy $(\mathrm{M}=0.57)$. For example, a primary school TL responded in the survey that she has, "integrated information literacy skills into the curriculum, lobbied the colleagues that students need to acquire information literacy skills, and worked with subject teachers to develop students' information literacy skills in subject context". On the other hand, primary $(M=0.00)$ and secondary school TLs $(M=-0.08)$ were neutral that they help educate subject teachers about information literacy. Both groups disagreed that they help parents understand information literacy (primary school TLs: $M=-0.22$; secondary school TLs: $M=-0.52)$.

Nevertheless, the finding shows that TLs in primary and secondary schools have incorporated information literacy in their teaching to a significantly different extent $(p=0.001)$. It was more likely for primary school TLs $(M=1.22)$ to agree that they teach information literacy during library lessons than secondary school TLs $(M=0.37)$. A primary school TL noted that, "I support students' project learning by teaching them to identify information source and search for relevant information", while another TL said that she, "provides instructional guidelines for students to search and find information properly during library lessons". This finding is consistent with the result shown in Figure 1 in the sense that primary school TLs spend more time on the preparation and delivery of library lessons than their secondary school counterparts.

Table 6: The Roles of TLs in Developing Stakeholders' Information Literacy

\begin{tabular}{|l|c|c|c|}
\hline \multicolumn{1}{|c|}{ Information literacy provision } & $\begin{array}{c}\text { Primary school } \\
\text { TLs } \\
(\mathrm{n}=28)\end{array}$ & $\begin{array}{c}\text { Secondary school } \\
\text { TLs } \\
(\mathrm{n}=28)\end{array}$ & $\begin{array}{c}\text { Sig. } \\
\text { Mann-Whitney }\end{array}$ \\
\cline { 2 - 4 } & Mean (SD) & Mean (SD) & $p$ value \\
\hline $\begin{array}{l}\text { I infuse elements of information } \\
\text { literacy in subject courses }\end{array}$ & $0.57(1.23)$ & $0.57(0.92)$ & 0.736 \\
\hline $\begin{array}{l}\text { I teach information literacy during } \\
\text { library lessons. }\end{array}$ & $1.22(0.80)$ & $0.37(0.97)$ & $0.001^{*}$ \\
\hline $\begin{array}{l}\text { I help educate other teachers about } \\
\text { information literacy. }\end{array}$ & $0.00(1.05)$ & $-0.08(0.98)$ & 0.772 \\
\hline $\begin{array}{l}\text { I help parents understand } \\
\text { information literacy. }\end{array}$ & $-0.22(1.15)$ & $-0.52(0.80)$ & 0.242 \\
\hline
\end{tabular}


Notes: * indicates $\mathrm{p}<.05$

-2=Strongly Disagree, $-1=$ Disagree, $0=$ Neutral, 1=Agree, 2=Strongly Agree

\section{Collaborating with teachers}

As shown in Table 7, primary and secondary school TLs have collaboration with other teachers to a similar extent. They cooperate with other teachers in library collection development (primary school TLs: $M=0.86$; secondary school TLs: $M=0.79$ ) and work together to prepare acquisition of curriculum resources and reference materials (primary school TLs: $M=1.04$; secondary school TLs: $\mathrm{M}=0.86$ ). A primary school TL commented that, "I am in charge of developing $80 \%$ of the library materials ... but in general meetings I encourage other teachers to request the materials they want to buy. For example, I work with religion studies and Chinese teachers to purchase more books in that particular subject for students to do their assignments". Compared to secondary school TLs, primary school TLs are significantly more active in promoting reading interest through course curriculum, activities and/or reading schemes $(p=0.009)$.

In contrast, both primary $(M=0.54)$ and secondary school $(M=0.14)$ TLs tended to be neutral that they work with teachers in collaborative teaching. It suggests that the level of collaboration between teachers and TLs in primary and secondary schools was very low indeed.

Table 7: Collaboration Between TLs and Teachers

\begin{tabular}{|c|c|c|c|}
\hline Types of TL collaboration & $\begin{array}{c}\text { Primary school } \\
\text { TLs } \\
(n=28)\end{array}$ & $\begin{array}{c}\text { Secondary school } \\
\text { TLs } \\
(n=28)\end{array}$ & $\begin{array}{c}\text { Sig. } \\
\text { Mann-Whitney }\end{array}$ \\
\hline & Mean (SD) & Mean (SD) & $p$ value \\
\hline $\begin{array}{l}\text { The school has guidelines on how } \\
\text { TLs can collaborate with subject } \\
\text { teachers. }\end{array}$ & $-0.29(1.33)$ & $-0.11(1.07)$ & 0.505 \\
\hline $\begin{array}{l}\text { I am clear about how subject } \\
\text { teachers can collaborate with me. }\end{array}$ & $0.75(0.11)$ & $0.21(0.99)$ & 0.051 \\
\hline \multicolumn{4}{|l|}{ I work with teachers to } \\
\hline $\begin{array}{l}\text { a. Collaboratively develop library } \\
\text { collection. }\end{array}$ & $0.86(0.85)$ & $0.79(1.03)$ & 0.978 \\
\hline $\begin{array}{l}\text { b. Prepare acquisition of curriculum } \\
\text { resources / reference materials. }\end{array}$ & $1.04(0.84)$ & $0.86(0.93)$ & 0.425 \\
\hline $\begin{array}{l}\text { c. Engage in collaborative teaching } \\
\text { (e.g., decide on topics of } \\
\text { information literacy to be covered } \\
\text { in subject courses). }\end{array}$ & $0.54(1.20)$ & $0.14(1.04)$ & 0.172 \\
\hline $\begin{array}{l}\text { d. Promote reading interest through } \\
\text { course curriculum / activities / } \\
\text { reading schemes }\end{array}$ & $1.43(0.57)$ & $0.83(0.79)$ & $0.009^{*}$ \\
\hline
\end{tabular}

Notes: * indicates $p<.05$

$-2=$ Strongly Disagree, $-1=$ Disagree, $0=$ Neutral, 1=Agree, 2=Strongly Agree

\section{Cultivating students' reading habits}

The findings in Table 7 suggest that primary and secondary school TLs share similar views on the facilitating factors in developing students' reading habits. They agreed on the importance of 4 listed factors: parents' nurturing, school's reading programs, a well-developed school library 
and services, and incorporation of reading initiatives into course curricula for cultivating students' reading habits.

Recognizing the importance of parents' role in nurturing children's reading, a primary school TL mentioned that, "we do have some parent-student reading activities. Every student is given a handbook so that they can go home and read with their parents and write reports". Another TL also actively recruited parent volunteers to participate in the reading program and, "they tell stories in Cantonese, English, and Mandarin".

In terms of schools' reading programs, primary school TLs are more inclined to consider it as an important factor for facilitating students' reading habits $(M=1.28)$. A primary school $T L$ commented that she "launched reading programs like peer reading sessions, story sharing competitions and World Reading Day", whereas another TL also noted that, "I organize some games for students so that they can feel more motivated to read these books as well. We will also invite some expatriate teachers to do some reading with students".

Table 8: Factors for Developing Students' Good Reading Habits

\begin{tabular}{|l|c|c|c|}
\hline \multicolumn{1}{|c|}{$\begin{array}{c}\text { Students develop good reading } \\
\text { habits through: }\end{array}$} & $\begin{array}{c}\text { Primary school } \\
\text { TLs } \\
(n=28)\end{array}$ & $\begin{array}{c}\text { Secondary school } \\
\text { TLs } \\
(n=28)\end{array}$ & Mann-Whitney \\
\cline { 2 - 4 } & Mean (SD) & Mean (SD) & $p$ value \\
\hline a. Parents' nurturing & $0.94(0.94)$ & $1.14(0.71)$ & 0.933 \\
\hline b. School's reading programs & $1.28(0.67)$ & $0.86(0.71)$ & 0.107 \\
\hline $\begin{array}{l}\text { c. A well developed school library } \\
\text { and services }\end{array}$ & $0.84(0.96)$ & $1.29(0.66)$ & 0.659 \\
\hline $\begin{array}{l}\text { d. Incorporation of reading initiatives } \\
\text { in course curriculum }\end{array}$ & $0.67(0.84)$ & $1.25(0.64)$ & 0.306 \\
\hline
\end{tabular}

Notes: * indicates $\mathrm{p}<.05$

$-2=$ Strongly Disagree, $-1=$ Disagree, $0=$ Neutral, 1=Agree, 2=Strongly Agree

\section{Conclusion and Limitations}

To conclude, the educational roles of TLs are generally acknowledged in this study. TLs shoulder the important tasks of developing information literacy and cultivating reading habits among students, and play a significant role in working with teaching staff on library collection development. Secondary school TLs participate in the instruction of subject courses, which is not conventionally regarded as a role for TLs. It is a pity, however, that their potential contribution to collaborative teaching with subject teachers is still underestimated, if not ignored, by contemporary curriculum planners and educators.

The present study has a number of limitations. Since the study lacks comprehensive evidence from other stakeholders such as students, teachers, parents and school administrators, it may limit understanding about the actual and perceived educational roles of TLs. Future studies could extend this work by comparing the roles of TLs in Hong Kong and other regions. A more sophisticated methodological design with a larger sample would allow future studies to better disentangle the educational roles of TLs and enhance the possibility of better integration of TLs into the local education system.

\section{References}


Abdullah, A. (1998). Competencies for teacher librarians in Malaysia. Dissertation (M.L.I.S.). The National University of Malaysia, Kuala Lumpur.

Association for the Teacher-librarianship in Canada, Canadian School Library Association (1998). Students' information literacy needs: competencies for teacher-librarians in the 21st century. Teacher Librarian, 26(2), 22-25.

Baule, S. (1999) Information power: Building partnerships for learning. Book Report, 18(3), 4243.

Broaddus, K., \& Ivey, G. (2002). Surprising the writer: Discovering details through research and reading. Language Arts, 80, 23-30.

Chu, S. K. W. (2009). Inquiry project-based learning with a partnership of three types of teachers and the school librarian. Journal of the American Society for Information Science and Technology, 60(8), 1671-1686.

Chu, S. K. W., Chow, K. \& Tse, S. K. (2011). Using collaborative teaching and inquiry projectbased learning to help primary school students develop information literacy and information skills. Library \& Information Science Research, 33, 132-143.

Chu, S. K. W., Tse, S. K., Loh, E. K. Y. \& Chow, K. (2011). Collaborative inquiry project-based learning: effects on reading ability and interests. Library \& Information Science Research, 33(3): 236-243.

Doskatsch, I. (2003). Perceptions and perplexities of the faculty-librarian partnership: An Australian perspective. Reference Services Review, 31, 111-121.

Fisher, D. (2008). Struggling adolescent readers. Teacher Librarian, 35(3), 36-37.

Haycock, K. \& Jopson, G. (1999). Propositions for information technology: Planning for success. Teacher Librarian, 26(3), 15-20.

Hylen, J. (2005). Help students and teachers become information literate. Teacher Librarian, 32(5), 22-24.

Kafai, Y., \& Bates, M. J. (1997). Internet web-searching instruction in the elementary classroom: Building a Foundation for Information Literacy. School Library Media Quarterly, 25, 103111.

Kuhlthau, C. 2003. Rethinking libraries for the information age school: Vital roles in inquiry learning. School Libraries in Canada, 22(4), 3-5.

Kuhlthau, C. C., Maniotes, L., \& Caspari, A. (2007). Guided inquiry: Learning in the 21st century. Westport, CT: Libraries Unlimited.

Lance, K. C., Welborn, L. \& Hamilton-Pennell, C. (1992). The impact of library media centres on academic achievement. Denver, CO: Colorado Department of Education. 
Lance, K. C., Rodney, M. \& Hamilton-Pennell, C. (2000). How school librarians help kids achieve standards: The second Colorado study. San Jose, CA: Hi Willow.McCarthy, P. J. (2002). Instruction collaboration: Imperative or imperilment? Colorado Libraries, 28, 34-35.

McCracken, A. (2001). School library media specialists' perceptions of practice and importance of roles described in information power. School Library Media Research, 4. Retrieved May 20, 2013, from

http://www.ala.org/aasl/aaslpubsandjournals/slmrb/sImrcontents/volume42001/mccracken

Mokhtar, I.A., \& Majid, S. (2006). An exploratory study of the collaborative relationship between teachers and librarians in Singapore primary and secondary schools. Library \& Information Science Research, 28, 265-280.

Ogunrombi, S. A., \& Adio, G. (1995). Factors affecting the reading habits of secondary school students. Library Review, 44(4), 50-57.

Rosenfeld, E., \& Loertscher, D. V. (Eds). (2007). Toward a 21st-Century school library media program. Lanham, MD: Scarecrow Press.

Scheirer, B. (2000). The changing role of the teacher-librarian in the twenty-first century. University of Saskatchewan. Retrieved May 20, 2013, from http://www.usask.ca/education/coursework/802papers/scheirer/sheirer.pdf

U.S. National Commission on Library and Information Science. (2003). The Prague declaration: Towards an information literate society. Retrieved May 20, 2013, from http://www.unesco.org/new/fileadmin/MULTIMEDIA/HQ/Cl/Cl/pdf/PragueDeclaration.pdf

Yip, S. Y. W. (2007). The role of a teacher-librarian in the New Senior Secondary (NSS) curriculum. Retrieved May 20, 2013, from http://www.edb.gov.hk/attachment/en/curriculumdevelopment/resource-support/sch-lib-services/role\%20of\%20TLs\%20in\%20NSS.pdf 